\title{
Organochlorine and organophosphorus pesticide residues in fodder and milk samples along Musi river belt, India
}

\author{
Korrapati Kotinagu and Nelapati Krishnaiah \\ Department of Veterinary Public Health and Epidemiology, College of Veterinary Science, Sri Venkateswara Veterinary \\ University, Hyderabad, India. \\ Corresponding author: Kotinagu Korrapati, e-mail: kotinagu@gmail.com, KN: drnkrishnaiah@yahoo.com \\ Received: 28-11-2014, Revised: 09-03-2015, Accepted: 18-03-2015, Published online: 29-04-2015
}

doi: 10.14202/vetworld.2015.545-550. How to cite this article: Kotinagu K, Krishnaiah N (2015) Organochlorine and organophosphorus pesticide residues in fodder and milk samples along Musi river belt, India, Veterinary World $8(4) ; 545-550$.

\begin{abstract}
Aim: The present study was conducted to find the organochlorine pesticide (OCP) and organophosphorus pesticide (OPP) residues in fodder and milk samples along Musi river belt, India.

Materials and Methods: Fodder and milk samples collected from the six zones of Musi river belt, Hyderabad India were analyzed by gas chromatography with electron capture detector for OCP residues and pulsated flame photometric detector for the presence of OPP residues.

Results: The gas chromatographic analysis of fodder samples of Zone 5 of Musi river showed the residues of dicofol at concentration of $0.07 \pm 0.0007$ (0.071-0.077). Among organophosphorus compounds, dimetheoate was present in milk samples collected from Zone 6 at a level of $0.13 \pm 0.006(0.111-0.167)$. The residues of OCPs, OPPs and cyclodies were below the detection limit in the remaining fodder and milk samples collected from Musi river belt in the present study.
\end{abstract}

Conclusion: The results indicate that the pesticide residues in fodder and milk samples were well below the maximum residue level (MRL) values, whereas dicofol in fodder and dimethoate in milk were slightly above the MRL values specified by EU and CODEX.

Keywords: fodder, gas chromatography, milk, Musi river, pesticide residues.

\section{Introduction}

Nowadays more than 800 different kinds of pesticides are used for control of insects, rodents, fungi and unwanted plants in the process of agricultural production. Although most of them leave the products or degrade in soil, water and atmosphere, these chemicals can be transferred to human via food chain [1]. Furthermore, breeding animals and their accommodation can themselves be sprayed with pesticide solution to prevent pest infestations. Consequently, both these contamination routes can lead to bioaccumulation of persistent pesticides in food products of animal origin such as meat, fat, fish eggs and milk [2,3]. Moreover, health departments also used these chemicals for controlling various insects having vector role in spreading the disease like malaria, dengue fever and plague [4,5]. Many pesticides and their residues have been reported as contributory factors in several diseases such as heart disease, cancers, Alzheimer's disease and parkinsonism [6,7]. Pesticide residues in feed and fodders may transfer into herbivores through food chain of the animals [8]. Due to the lipophilic nature of these pesticides, milk and other fat-rich substances are the key items for their accumulation. These toxicants get

Copyright: The authors. This article is an open access article licensed under the terms of the Creative Commons Attributin License (http:// creativecommons.org/licenses/by/2.0) which permits unrestricted use, distribution and reproduction in any medium, provided the work is properly cited. into the human body through the food chain and cause serious health problems [7].

Musi river is located on the Deccan platue in the state of Andhra Pradesh, India. However, now the water is highly polluted as 600 million liters per day of untreated sewage water is discharged into Musi river, additionally 14 industrial estates drain their untreated effluents into this river. The agricultural drained water is another source of pollution and this river water is rich in heavy metals, pesticide residues, phenols, oils, grease, alkalis and acids [9]. The self-purifying property of river water is unable to clear the pollution, and the polluted water poses a serious risk to public health especially in areas where river water is used for irrigation.

Keeping this in view of the Musi river pollution and its direct or indirect effect on environment, animal and human system, a study was conducted to analyze the fodder and milk samples on the banks of river Musi for the presence of pesticide residues. The study has been conducted on river Musi, Located in Andhra Pradesh, India.

\section{Materials and Methods}

\section{Ethical approval}

No animals were harmed or given stress during the collection of milk samples.

\section{Collection of samples}

This study was based on 48 fodder and 48 milk samples collected from six divided zones ( 8 from each 
zone) (Table-1) on the downstream of Musi river belt, Andhra Pradesh, India in 2013. Zones were divided based on earlier reports on Musi river pollution by Pullaiah [9]. Approximately, $250 \mathrm{~g}$ of fodder samples were collected in sterilized polyethylene packs, packed and transported to lab. Sterilized glass bottles were used to collect $250 \mathrm{ml}$ milk samples, labeled and transported to lab in ice pack, they were kept at $4^{\circ} \mathrm{C}$ until analysis. Samples were subjected to analysis within $24 \mathrm{~h}$ from their arrival.

\section{Pesticides analyzed}

The residues of certain pesticides of organochlorine viz., dichlorodiphenyltrichloroethane (DDT) (o,p'-dichlorodiphenyldichloroethylene [DDE], $\mathrm{o}, \mathrm{p}$ '-dichlorodiphenyldichloroethane [DDD], p,p'DDT and o,p'-DDT), dicofol, HCH Isomers (alpha, beta, gamma, delta), cyclodiene compounds (aldrin, endosulfan sulfate and heptachlor) and organophosphates (triazophos, dimetheoate, chlorpyrifos and methyl-chlorpyrifos) in fodder and milk samples collected from six zones of Musi river belt area.

\section{Chemicals and reagents}

Acetonitrile, acetone, dichloromethane, graphitized carbon black, hexane, magnesium sulfate, silica gel, sodium chloride, sodium sulfate, prostate specific antigen (PSA) of high-performance liquid chromatography residue grade obtained from Qualigens and Merck specialties Pvt. Ltd. Analytical standards with $>99 \%$ purity were obtained from Dr. Ehrenstorfer, Germany during 2012 and stored in deep freeze maintained at $-40^{\circ} \mathrm{C}$.

\section{Method validation}

The required quantity of (organochlorine and organophosphorus) international standards prepared from certified reference materials were added to each $15 \mathrm{~g}$ sample to get fortification levels of $0.05 \mathrm{ppm}$ and $0.1 \mathrm{ppm}$ in three replications each. The AOAC official method 2007.01 with slight modifications was validated for the estimation of the limit of quantification (LOQ) of organochlorine and organophosphorus in fodder and milk. Fodder samples were chopped, and $7.5 \mathrm{~g}$ of sample was taken into $50 \mathrm{ml}$ centrifuge tubes

Table-1: Selected zones and covered areas along the Musi river belt, Telangana, India.

\footnotetext{
Zone Areas covered along Musi river belt

1 Attapur, Langer House, Upper pally, Kishan Bagh, Bahadurpura, Puranapool, Budvel, High court.

2 Chadhar ghat, Malakpet, Morarambagh, Golnaka, Amberpet, Ramanthapur, Nagole, Uppal.

3 Peerzadiguda, K. singaram, Thimaiguda, Pratapa singaram, Korremulla, Bacharam, Bandaraviral, Chinna raviralla.

4 Pillai Palli, Rudravelly, Brahmanapally, Venkiryala, Edulabad, Nadama Khada, Shivareddy gudem, Alinagar.

5 Indriyala, D.R.palli, Wankamamidi, Shaligowraram, Dharmaram, Chittur, Jajireddygudem, Manimadde.

6 Musi reservoir, Yendlapally, Kasarabad, Beemavaram, Dasaphad, M.gudem, Irkigudem, Wazirabad.
}

and $30 \mathrm{ml}$ of acetonitrile was added and shaken well. The sample was homogenized at 14000-15000 RPM for 2-3 min using heidolp silent crusher then $3 \mathrm{~g}$ of sodium chloride was added, mixed well by shaking gently then it was centrifuged at 2500-3000 RPM for 3 min to separate the organic layer, approx. $16 \mathrm{ml}$ of organic layer was taken into a test tube and $9 \mathrm{~g}$ of anhydrous sodium sulfate was added to remove moisture [1]. Taken about $0.4 \mathrm{~g}$ PSA sorbent and $1.2 \mathrm{~g}$ anhydrous magnesium sulfate into $15 \mathrm{ml}$ centrifuge tubes. The $8 \mathrm{ml}$ of organic layer extract was transferred into this $15 \mathrm{ml}$ centrifuge tube, capped and vortex for $30 \mathrm{~s}$, then tubes were centrifuged at 2500-3000 RPM for $5 \mathrm{~min}$ then $2 \mathrm{ml}$ of extract was transferred into test tubes and the solvent (acetonitrile) was evaporated turbovap concentrator for GC analysis. Whereas for milk samples, $5 \mathrm{~g}$ of milk was taken into $250 \mathrm{ml}$ beaker and $20 \mathrm{~g}$ of silica gel and $20 \mathrm{~g}$ of anhydrous sodium sulfate was added. Glass column was prepared with $40 \mathrm{ml}$ of dichloromethane over cotton plug, sample was made into slurry with dichloromethane then this was transfer to column and allowed to stand for 90 min then dichloromethane was eluted dropwise, again the sample column was eluted with a mixture of $150 \mathrm{ml}$ acetone: Dichloromethane $(2: 1 \mathrm{v} / \mathrm{w})$ and anhydrous sodium sulfate was added to the elute, then concentrated to 2-3 ml, 10-15 $\mathrm{ml}$ of hexane was added to the concentrate to remove dichloromethane completely, volume was made with n-hexane. Finally, an aliquot of each extract was transferred to $2 \mathrm{ml}$ injection vials to be ready for the analysis.

A Schimadzu 2010 gas chromatography (GC) equipment with a VF-1MS capillary column and with electron capture detector (ECD) and flame photometric detector. All the chemicals were purchased from M/s. Merck specialties Pvt. Ltd and were pesticide residue grade and all pesticide residue standards were purchased from Dr. Erhenstorfer, Germany during 2012. The gas chromatographic analysis was performed under the following conditions (Table-2). A volume of $1 \mathrm{ml}$ sample was injected into the GC; peaks were identified by comparing their retention times with those of standards under the same injection conditions (Table-3). The peak areas of the various peaks whose retention times coincide with the standards were extracted on their corresponding calibration curves to obtain the concentrations.

\section{Results and Discussion}

A total of 48 fodder samples and 48 milk samples collected from all the six zones of Musi river belt and were analyzed for OCPs and OPPs residues. Concentration of various residues in each sample was calculated (in $\mathrm{mg} / \mathrm{kg}$ sample). In the present study, the average recoveries of OCPs in fodder were from $88.05 \%$ at $0.05 \mathrm{ppm}$ and $86.71 \%$ at $0.1 \mathrm{ppm}$ and in milk were from $88.45 \%$ at $0.05 \mathrm{ppm}$ and $91.25 \%$ at $0.1 \mathrm{ppm}$. Average recoveries of OPPs in fodder were $91.27 \%$ at $0.05 \mathrm{ppm}$ and $94.67 \%$ at $0.1 \mathrm{ppm}$ and in 
milk were from $91.25 \%$ at $0.05 \mathrm{ppm}$ and $86.77 \%$ at $0.1 \mathrm{ppm}$. The efficiency of extraction methodologies were evaluated based on the recoveries of residues, and a recovery of $75-102 \%$ is considered as acceptable [10]. Hence, the extraction procedures employed in these experiments were efficient in recovering the maximum amount of residues present in the samples. The elute pattern of various OCPs (0.01 ppm) (Figure-1) and OPPs $(0.05 \mathrm{ppm})$ along with specific retention time are depicted in Figure-2 for ECD and Figure-3 for pulsated flame photometric detector (PFPD). The limit of detection and LOQ for OCPs was $0.01 \mathrm{ppm}$ and $0.05 \mathrm{ppm}$ respectively and for OPPS was $0.05 \mathrm{ppm}$ and $0.05 \mathrm{ppm}$ respectively for both ECD and PFPD.

OCPs compounds p,p'-DDE, o,p'- DDD, p,p'DDT,o,p'-DDT, Total DDT, dicofol, alpha HCH, beta $\mathrm{HCH}$, gamma $\mathrm{HCH}$, delta $\mathrm{HCH}$, cyclodiene

Table-2: Details of GC operating parameters.

\begin{tabular}{ll}
\hline GC & GC-Schimadzu $\mathbf{2 0 1 0}$ \\
\hline Column & VF-1 ms capillary column \\
& 30 m length, $0.25 \mathrm{~mm}$ \\
& internal diameter, \\
& $0.25 \mathrm{~mm}$ film thickness; \\
& $1 \%$ methyl siloxane \\
& 260 (isothermal) \\
Column oven $\left({ }^{\circ} \mathrm{C}\right)$ & ECD \\
Detectors & FPD \\
& 280 \\
Detector temperature $\left({ }^{\circ} \mathrm{C}\right)$ & 260 \\
Injector temperature $\left({ }^{\circ} \mathrm{C}\right)$ & Front injector \\
Injector status & type 1177 split/splitless \\
& Split ratio: $1: 5$ \\
Carrier gas & Nitrogen, Iolar II, Purity \\
& $99.99 \%$ \\
Carrier gas flow $\left(\mathrm{ml} \mathrm{min}^{-1}\right)$ & $1 \mathrm{ml} / \mathrm{min}$ \\
Make-up flow $\left(\mathrm{ml} \mathrm{min} \mathrm{min}^{-1}\right)$ & $35 \mathrm{ml} / \mathrm{min}$ \\
Total run time $(\mathrm{min})$ & $60 \mathrm{~min}$ \\
\hline
\end{tabular}

$\mathrm{ECD}=$ Electron capture detector, $\mathrm{FPD}=$ Flame photometric detector, GC=Gas chromatography

Table-3: Details of retention times of OCPs and OPPs under ECD and PFPD.

\begin{tabular}{lcc}
\hline Retention time & ECD & PFPD \\
\hline 4,4 DDE & 27.171 & - \\
2,4-DDD & 28.539 & - \\
4,4 DDT & 31.312 & - \\
2,4-DDT & 29.081 & - \\
Alpha-HCH & 14.434 & - \\
Beta-HCH & 18.006 & - \\
Gamma-HCH & 16.177 & - \\
Delta-HCH & 19.366 & - \\
Aldrin & 22.026 & - \\
Endo sulfate & 33.090 & - \\
Heptachlor & 19.704 & - \\
Dicofol & 24.082 & - \\
Triazophos & 37.406 & 37.406 \\
Dimethoate & 15.300 & 15.196 \\
Chlorpyrifos & 22.111 & 22.111 \\
ME-chlorpyrifos & 18.925 & 18.925 \\
\hline DDE=Dichlorodiphenyldichloroethylene, & \\
DDD=Dichlorodiphenyldichloroethane, & \\
DDT=Dichlorodiphenyltrichloroethane, ECD=Electron \\
capture detector, PFPD=Pulsated flame photometric detector
\end{tabular}

compounds aldrin, endosulphan sulfate, heptachlor and organophosphorus compounds triazophos, methyl

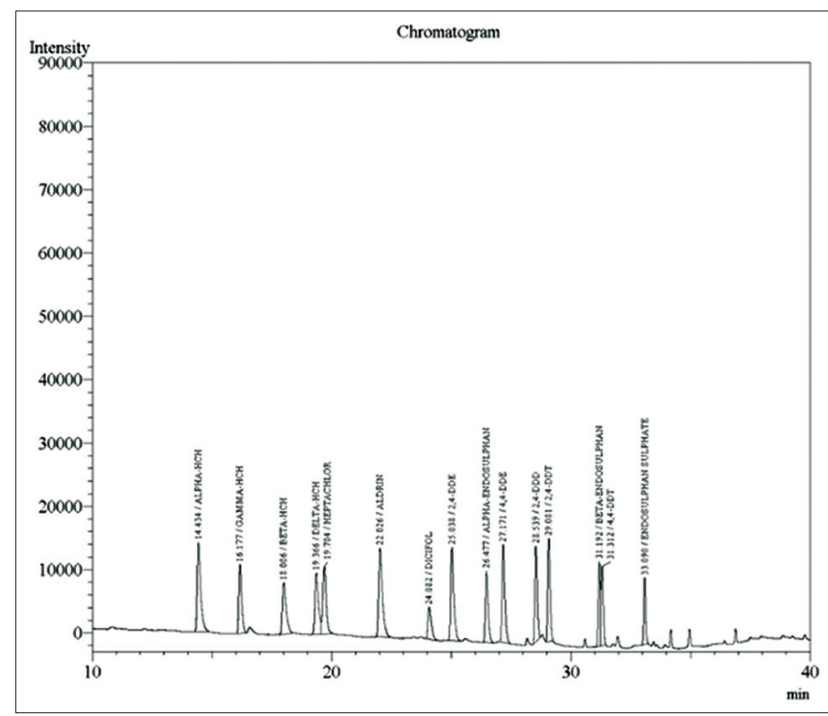

Figure-1: Elution pattern of oranochlorine pesticide standard mixture $(0.1 \mathrm{ng})$.

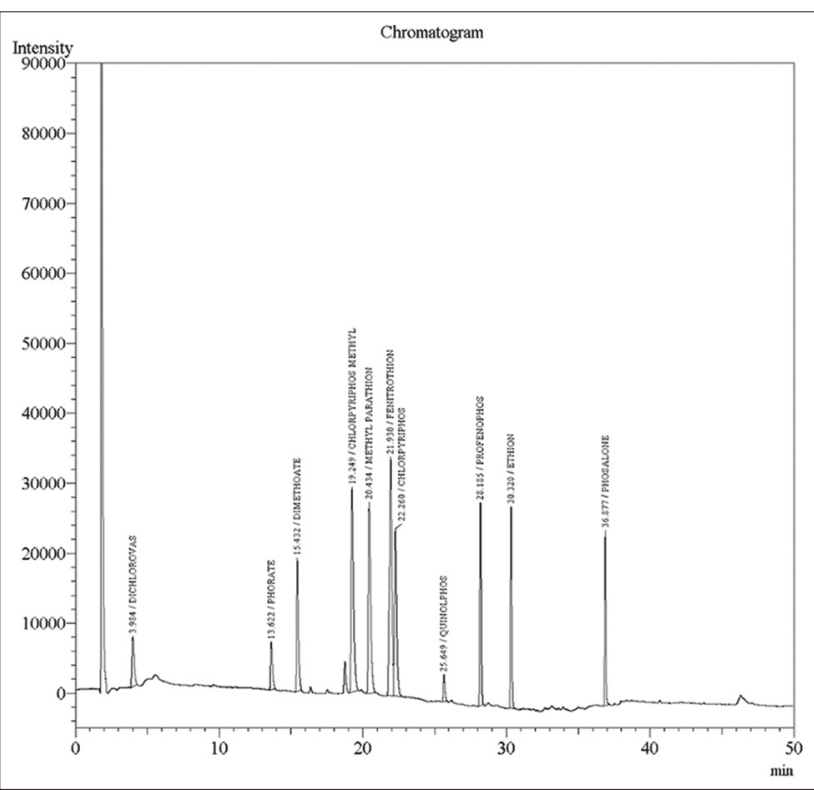

Figure-2: Elution pattern of organophosphorus pesticide standards mixture by electron capture detector.

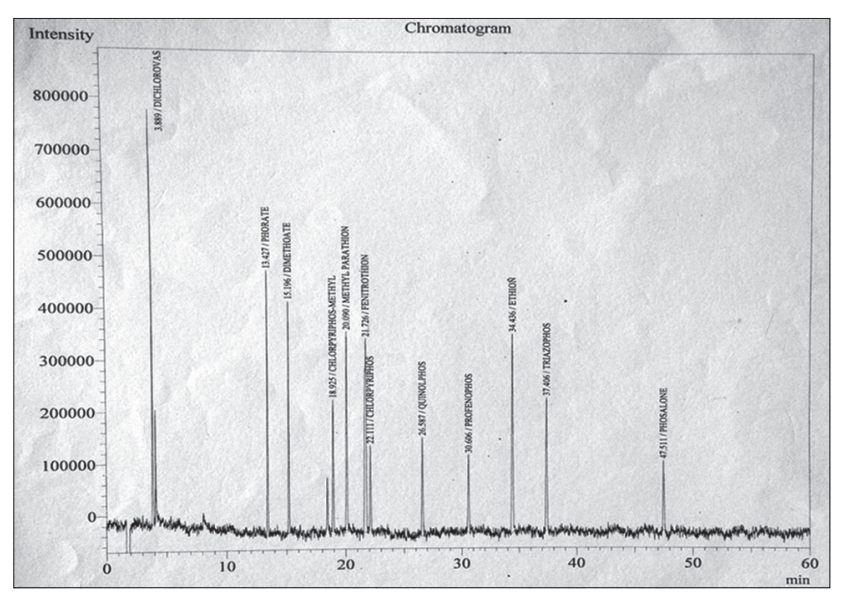

Figure-3: Elution pattern of organophosphorus pesticide standards mixture by pulsated flame photometric detector. 
chlorpyrifos, chlorpyrifos and dimethoate were analyzed in fodder samples collected from Musi river belt. Fodder samples collected from zone V contain the residual concentration of dicofol of $0.07 \mathrm{ppm}$ (Figure-4) and other organochlorine, organophosphorus and cyclodiene compounds were below detection limit in all other fodder samples in the present study (Table-4).

The prevalence of residues of $p, p^{\prime}$ DDE, $p, p$ ' DDT and total DDT in fodder was $5 \%, 60 \%$ and $3 \%$ respectively, was reported by Nagra [11]. Residue levels of o,p' DDT of $0.006 \mathrm{ppm}$ in fodder was reported by Panseri [12]. A residue levels of total DDT of $0.17 \mathrm{ppm}$ in fodder was reported by Nagra [11].

$\alpha-\mathrm{HCH}$ and $\beta-\mathrm{HCH}$ residue levels of $0.002 \mathrm{ppm}$ and $0.003 \mathrm{ppm}$ respectively in fodder was reported by Panseri [12].

Residue levels of aldrin of $0.004 \mathrm{ppm}$ and $0.03 \mathrm{ppm}$ in fodder were reported by Panseri [12] and Nagra [11] respectively. A residue level of $0.007 \mathrm{ppm}$ and $0.045 \mathrm{ppm}$ was reported by Panseri [12] and Deka [13] in fodder samples, which is far below the specified MRL value by EU(CE: 698: 2005) is $0.1 \mathrm{ppm}$, whereas higher levels $(0.42 \mathrm{ppm})$ was reported by Aulakh [14] for endosulphan sulfate. Residual concentration of $0.001 \mathrm{ppm}$ and $0.02 \mathrm{ppm}$ were reported by Panseri [12] and Aulakh [14] respectively in the fodder samples, which are far below the MRL value (0.01 ppm) specified by EU (CE:398: 2005) in fodder for heptachlor. Fagnani et al. [15] reported the residual concentration of dimethoate in fodder sample as $0.01 \mu \mathrm{gl}^{-1}$.

For milk samples also the same OCP compounds, cyclodiene compounds and organophosphorus compounds conducted for fodder samples were analyzed. Milk samples from zone V contain the residual concentration of dimithioate of $0.13 \mathrm{ppm}$ (Figure-5), which is higher than concentrations of $0.01 \mu \mathrm{gl}^{-1}$ for dimithioate reported by Fagnani et al. [15]. In the

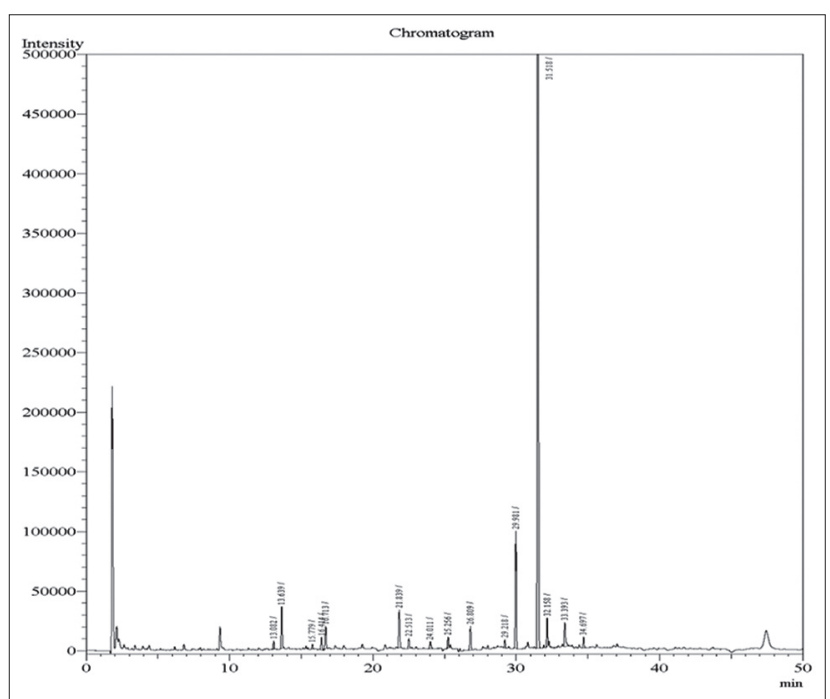

Figure-4: Elution pattern of dicofol from fodder samples of Zone 5 of the Musi river belt.

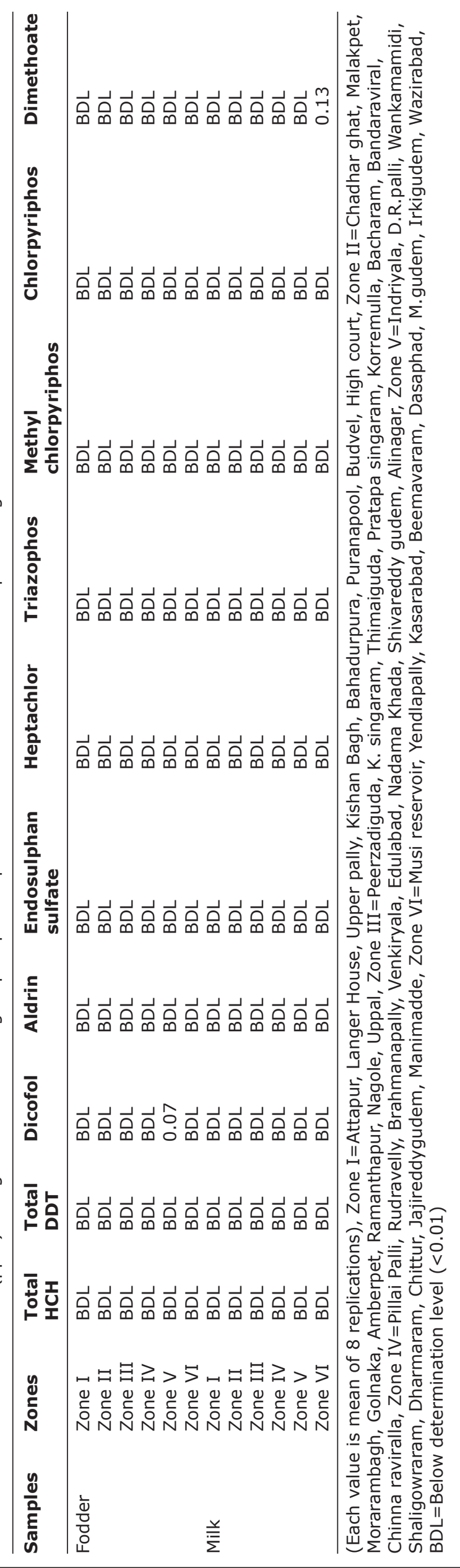




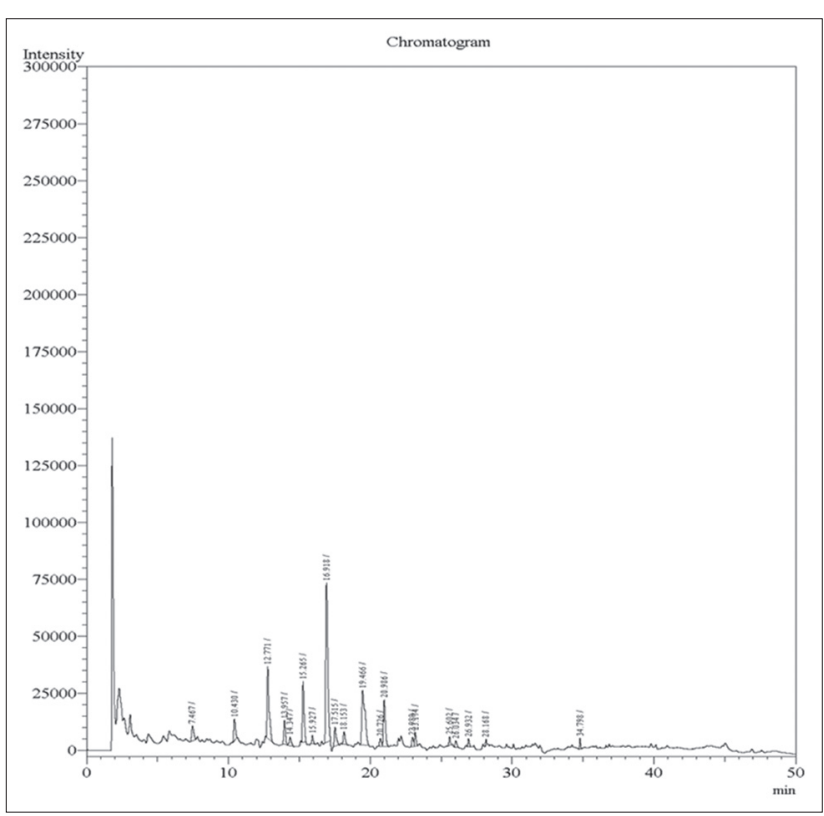

Figure-5: Elution pattern of organophosphorus pesticide residues in milk samples from zone 6 of the Musi river belt.

present study except dimithioate all other OCPs compounds, cyclodiene compounds and organophosphorus compounds were below the detection limit in milk samples.

The levels of PP DDE were $0.028 \mathrm{ppm}$ in cow milk [16] and 0.039 ppm in mixed milk [17]. Donia [16] reported $0.014 \mathrm{ppm}$ and $0.009 \mathrm{ppm}$ levels of o,p' DDD in buffalo and cow milk respectively. These findings are far below than the MRL value of $1.25 \mathrm{ppm}$ for milk specified by PFA [18]. The residues of o,p' DDD of $0.002 \mathrm{ppm}$ was reported by Panseri [12], which is far below than the MRL level (0.05 ppm) specified by EU (CE: 698: 2005). Residue levels of P'P'- DDT of 0.038 and $0.033 \mathrm{ppm}$ were reported by Mohd Aslam [19] and Kampire et al. [20] respectively.

Donia [16] reported $0.022 \mathrm{ppm}$ and $0.032 \mathrm{ppm}$ in buffalo and cow milk respectively, whereas Waliszewski et al. [21] reported residue levels of 0.0372 and 0.078 in mixed milk for p,p' DDT. Residue levels of $0.007 \mathrm{ppm}$ and $0.056 \mathrm{ppm}$ in milk were reported by Cerkvenik [22] and Radzyminska [23] respectively, which were below than the MRL value (0.04 ppm) of EU (CE:698: 2005) for o,p' DDT.

Residue levels of $\alpha-\mathrm{HCH}$ of $0.003 \mathrm{ppm}$, $0.008 \mathrm{ppm}$ and $0.013 \mathrm{ppm}$ were reported by Ahmed and Zaki [24], Cerkvenik [22] and Pardio [17] respectively, which were below than the MRL value (1.25 ppm) of EU (CE: 698: 2005). The $\beta$-HCH prevalence of $16.67 \%$ and a level of $0.003 \mathrm{ppm}$ were reported by Ahmed and Zaki [24].

Residue levels of aldrin at a level of $0.004 \mathrm{ppm}$ were reported by Ahmed and Zaki [24] in mixed milk, whereas $0.066 \mathrm{ppm}$ and $0.036 \mathrm{ppm}$ were reported by Donia [16] in buffalo milk and cow milk respectively. All the values reported by the above scientists were below than the MRL value $(0.2 \mathrm{ppm})$ of EU
(CE: 698: 2005). For endosulphan sulfate, the residue levels of $0.002 \mathrm{ppm}$ and $0.26 \mathrm{ppm}$ were reported by Ahmed and Zaki [24] and Muhammad [25] respectively and prevalence of $9.09 \%$ was reported by Ahmed and Zaki [24] in mixed milk sample. The residue levels of heptachlor of $0.003 \mathrm{ppm}$ and $0.022 \mathrm{ppm}$ were reported by Cerkvenik [22] and Donia et al. [16] respectively, A prevalence of $16.16 \%$ of heptachlor was reported by Ahmad and Zaki [24] in mixed milk.

\section{Conclusion}

From this study, it can be concluded that all the pesticide residues in fodder and milk samples were below the MRL except dicofol in fodder and dimethoate in milk were slightly above the MRL values specified by EU and CODEX it might be due to use of these pesticides on vegetable crops grown on the banks of Musi river belt. However, the results of OPPs in different samples were detected by ECD and confirmed by PFPD, whereas O.C.'s were detected by only ECD but not confirmed by Mass Spectrometry due to non-availability of equipment. Owing to effects on human, animal and environmental health of pesticide residues need for education and awareness among farmers about extensive use of pesticide was envisaged.

\section{Authors' Contributions}

Both authors have designed the plan of work. KK carried out the sample collection, laboratory work and analyzed the results. KK and $\mathrm{KN}$ drafted and revised the manuscript. Both authors read and approved the final manuscript.

\section{Acknowledgments}

Authors are grateful to the college of veterinary science, Sri Venkateshwara Veterinary University, Hyderabad, India for giving financial support to the present research project and also thankful to the Administrative Authorities of All India network project on pesticide residues, Acharya N.G. Ranga Agricultural University, Hyderabad, for their laboratory support and encouragement.

\section{Competing Interests}

The authors declare that they have no competing interests.

\section{References}

1. Benbrook, C.M. (2002) Organ chlorine Residues pose surprisingly high dietary risks. J. Epidemiol. Community Health., 56(11): 822-823.

2. Lehotay, S.J., Mastovska, K. and Yun, S.J. (2005) Evaluation of two fast and easy methods for pesticide residues analysis in fatty food matrices. J. AOAC Int., 88(2): 630-638.

3. Qiu, X., Zhu, T., Yao, B., Hu, J. and Hu, S. (2005) Contribution of dicofol to the current DDT pollution in China. Environ Sci. Technol., 39(12): 4385-4390.

4. John, P.J., Bakore, N. and Bhatnagar, P. (2001) Assessment of organochlorine pesticide residues levels in dairy milk and buffalo milk from Jaipur city, Rajasthan. India Environ. Int., 26(4): 231-236. 
5. Berg, H.V.D., Velayndhan, R., Ebol, A., Catbagan, B.H.G, Jr., Turingan, R., Tuso, M. and Hii, J. (2012) Operational effiency and sustainability of vector control of malaria and dengue: Descriptive case studies from the Philippines. Malaria J., 11: 269.

6. Khaniki, G.R. (2007) Chemical contaminants in milk and public health concerns: A review. Int. J. Dairy Sci., 2: $104-115$.

7. Tsiplakou, E., Anagnostopoulos, C.T., Liapis, K., Haroutounian, S.A. and Zervas, G. (2010) Pesticides residues in milk and feed stuff of farm animals drawn from greece. Chemosphere., 80(5): 504-512.

8. Prassad, K.S.N. and Chhabra, A. (2001) Organochlorine pesticide residues in animal feeds and fodders. Indian $J$. Anim. Sci., 71: 1178-1180.

9. Cheepi, P. (2013) Assessing the economic impact of water pollution - A case study of musi river Hyderabad, India. Int. Res. J. Soc. Sci., 2(1): 18-23.

10. Solymos, M., Visi, E., Karoly, G., Beke Berezi, B. and Gyorfi, L. (2001) Comparison of extraction methods to monitor pesticide residues in surface water. J. Chromatogr. Sci., 39(8): 325-331.

11. Nagra, R.K. (2006) Studies on insecticide residues in feed and fodder in Punjab. M.V.Sc. Thesis, GADVAS University, Ludhiana, India.

12. Panseri, S., Biondi, P.A., Vigo, D., Communod, R. and Chiesa, L.M. (2013) Occurrence of organochlorine pesticides residues in animal feed and fatty bovine tissue. Food Industry, Dr. Innocenzo Muzzalupo (Ed.), ISBN: 978953-51-0911-2, InTech, DOI: 10.5772/54182. Available from: http://www.intechopen.com/books/food-industry/ occurrence-of-organochlorine-pesticides-residues-in-animal-feed-and-fatty-bovine-tissue. Last accessed on 15-11-2014.

13. Deka, S.C., Barman, N. and Baruah, A.A.L.H. (2004) Monitoring of pesticide residues in feed, fodder and butter in Assam. Pestic. Res. J., 16: 86-89.

14. Aulakh, R.S., Gill, J.P.S., Bedi, J.S., Sharma, J.K., Joia, B.S. and Ockerman, H.W. (2006) Organochlorine pesticide residues in poultry feed, chicken muscle and eggs at a poultry farm in Punjab, India. J. Sci. Food Agric., 86: 741-744.
15. Fagnani, R., Beloti, V., Battaglini, A.P.P., Dunga, K.S. and Tamanini, R. (2011) Organophosphorus and carbamates residues in milk and feedstuff supplied to dairy cattle. Pesq. Vet. Bras., 31(7):598-602.

16. Donia, M.A.A., Abou-Arab, A.A.K., Enb, A., El-Senaity, M.H. and Abd-Rabou, N.S. (2010) Chemical composition of raw milk and the accumulation of pesticide residues in milk products. Glob. Vet., 4(1): 6-14.

17. Pardio, V.T., Waliszewski, K.N., Landin, L.A. and Bautista, R.G. (2003) Organochlorine pesticide residues in cow's milk from a tropical region of Mexico. Food Addit. Contam., 20(3): 259-269.

18. PFA. (2004) Prevention of Food Adulteration Act, 2004. Available from: http://www.mohfw.nic.in/. Accessed on 01-10-2004.

19. Aslam, M., Rais, S. and Aslam, M. (2013) Quantification of organochlorine pesticide residues in buffalo milk samples of Delhi city, India. J. Environ. Prot., 4: 964-974.

20. Kampire, E., Kiremire, B.T., Nyanz, S.A. and Kishimba, M. (2011) Organochlorine pesticide in fresh and pasturized cow's milk from Kampala markets. Chemosphere., 84(7): 923-927.

21. Waliszewski, S.M., Villalobos-Pietrini, R., GomezArroyo, S. and Infanzon, R.M. (2003) Persistent organochlorine pesticide levels in cow's milk samples from tropical regions of Mexico. Food Addit. Contam., 20(3): 270-275.

22. Cerkvenik, V., Doganoc, DZ. and Jan, J. (2000) Evidence of trace elements, pesticides and PCBs in milk. Food Technol. Biotechnol., 38(2): 155-160.

23. Radzymińska, M., Smoczyński, S.S. and Kopeć, M. (2007) Persistent organochlorine pesticide, lead, cadmium, nitrate (V) and nitrate (III) in polish milk and dairy products. Pol. J. Environ. Stud., 17(1): 95-100.

24. Ahmed, N.S. and Zaki, M.S. (2009) Detection of some organochlorine pesticides in raw milk in giza governorate. J. Appl. Sci. Res., 5(12): 2520-2523.

25. Muhammad, F., Javed, I., Akhtar, M., Rahman, Z.U., Awais, M.M., Saleemi, M.K. and Anwar, M.I. (2012) Quantitative structure activity relationship and risk analysis of some pesticides in the cattle milk. Pak. Vet. J., 32(4): 589-592.

\section{$* * * * * * * *$}

